Zadoks, J. C., T. T. Chang \& C. F. Konzak, 1974. A decimal code for the growth stages of cereals. Eucarpia Bulletin 7; $11 \mathrm{pp}$.

This synopsis is based on an M.Sc. thesis by J.J. R. Groot \& H.J. W. van Roermund entitled 'Simulatie van opbrengstderving door bladluizen in wintertarwe', Department of Theoretical Production Ecology, Agricultural University, Wageningen, 1985. 137 pp., 29 figs., 13 tables, 41 refs. Dutch.

Available as paper copy (order R057P, $f 30$ including postage) or microfiche (order R057M, f 17.50 including postage) at: NARD, clo Pudoc, P.O. Box 4, 6700 AA Wageningen, Netherlands (telex 45015 blhwg $\mathrm{nl}$ ).

\title{
Crown shyness: a parameter for ageing in Piptadeniastrum africanum
}

D. M. J. Offermans (Department of Silviculture, Agricultural University, P.O. Box 342, 6700 AH Wageningen, Netherlands)

Received 15 April 1986; accepted 30 June 1986

Abstract. The ageing of Piptadeniastrum africanum within the forest follows a welldefined pattern, that consists of different stages, which can be determined from large-scale stereoscopic aerial photographs. The main parameters of this pattern are branch orientation, crown stratification, depth of foliage and crown shyness.

Crown shyness indicates a phase of declining vigour of $P$. africanum and is seen as a parameter for ageing in the senescent stages of the life of $P$. africanum.

Key words: Piptadeniastrum africanum, ageing characteristics, crown morphology, crown shyness, senescence, aerial photography.

Introduction. Vooren (in prep.) proposes a silvicultural system for tropical forests, in which harvesting is modelled on the natural mortality process within the forest and harvest-ripe trees are detected by means of aerial observations. This study was set up to contribute to the insight in the structure and the evolution of mature treecrowns and to establish parameters for this evolution, which can be evaluated by remote sensing techniques.

Materials and methods. Crown alteration was studied on $P$. africanum, a common species in Africa with potential commercial value (Anon., 1974). The species is easily recognizable and accessible for both ground and aerial observations. Its architectural growth model (Troll's) was described by Hallé et al. (1978). 


\section{M. J. OFFERMANS}

The study is based on observations of forest specimens of $P$. africanum in the Tai and the Banco National Parks, South Ivory Coast. 55 trees of $30 \mathrm{~cm}$ diameter and larger were sampled, as these are sufficiently dominant to be visible on large-scale aerial photographs.

The aerial photographs were obtained by the use of an ultralight aircraft (Vooren \& Offermans, 1985; Offermans, in press). Black-and-white films were used to cover the spectrum in the visible, and in the reflective infrared.

Nine individuals of $P$. africanum were covered stereoscopically on large-scale aerial photographs (negative scales from 1:800 to 1:4000), six out of which were included in the ground mensurations.

The ageing stages of $P$. africanum. The ageing of $P$. africanum in the forest follows a well-defined pattern of successive ageing stages. The main characteristics of the sequence are branch orientation, crown stratification, depth of foliage and crown shyness (Fig. 1a).

The stages I to III are the competitive stages of $P$. africanum, before the forest canopy is reached. In stage I the tree is characterized by a densily leaved crown with

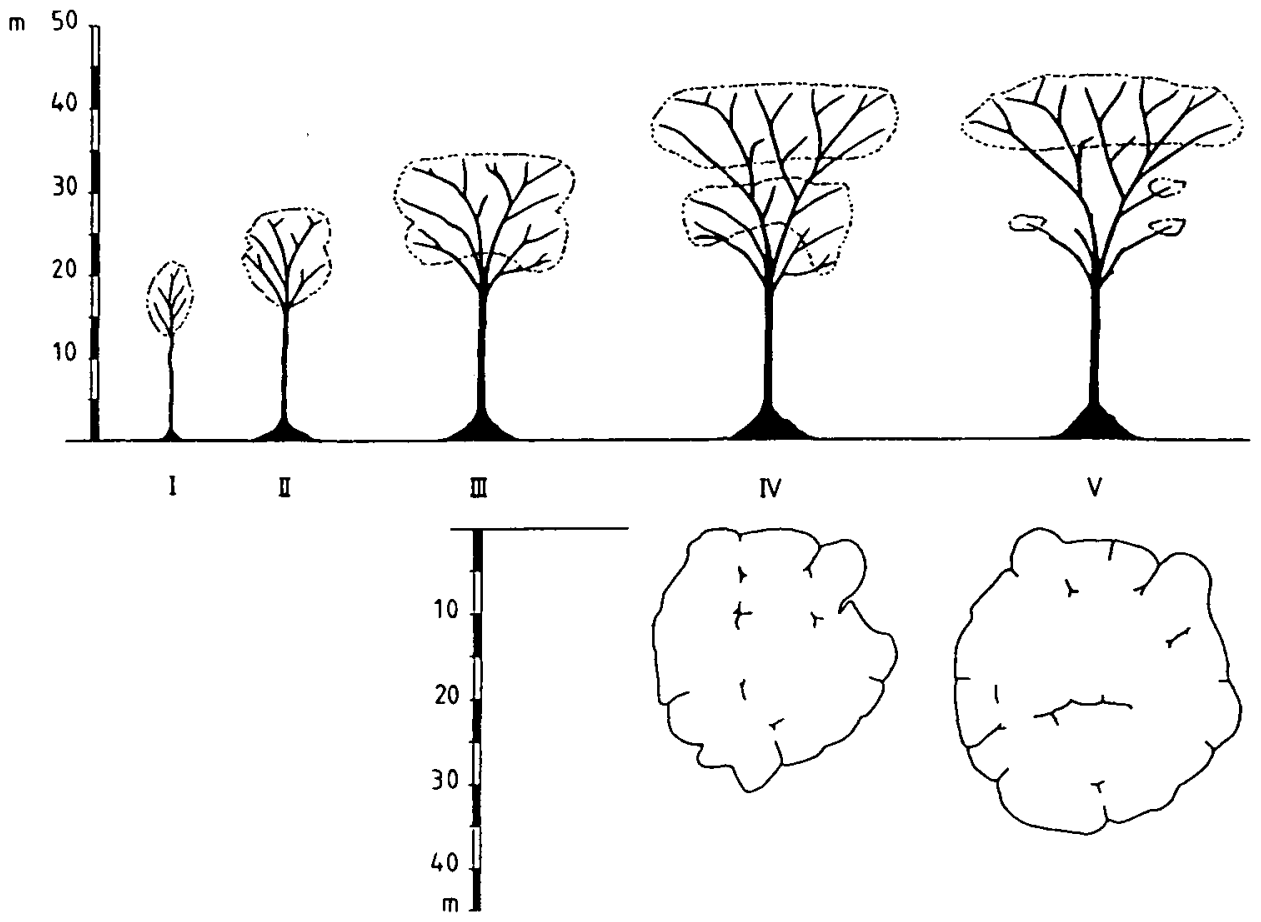

Fig. 1a (top). Stages I-X. Ageing sequence of Piptadeniastrum africanum in the forest.

Major branches are drawn in black. The foliage is outlined by dots. Stage VI represents the transition from the non crown-shy stage (VIa, left crown part) to the crown-shy stage (VIb, right crown part). 
steeply ascending main branches. Apart from a vague separation, arising between the upper and the lower crown parts, the two following stages mainly show dimensional changes.

In the stages IV to VIa the tree crown expands above the forest canopy. The vertical branch orientation changes, as branches develop a distal plagiotropic and a proximal orthotropic segment (cf. Hallé et al., 1978). In stage IV a complete separation between the upper and the lower crown part has developed. During the following stages the decay of the lower crown part takes place parallel to the lateral extension of the crown. Light conditions within the tree crown are considered to account for both the existence of an exclusion volume between the two crown parts and the decay of the lower part of the crown (cf. Alexandre, 1983).

The final stages, VIb to $\mathrm{X}$, are the stages of declining vigour, which are accompanied by senescence (cf. Leopold, 1975) and the feature of crown shyness. The crown breaks up into smaller units, the sub-crowns (Fig. 1b). Each sub-crown respects a certain distance to neighbouring sub-crowns. With ageing, this distance increases. Offermans (1986) proposed the ratio between the cumulative surface of the sub-crowns and the total crown surface as a measure for crown shyness. In the
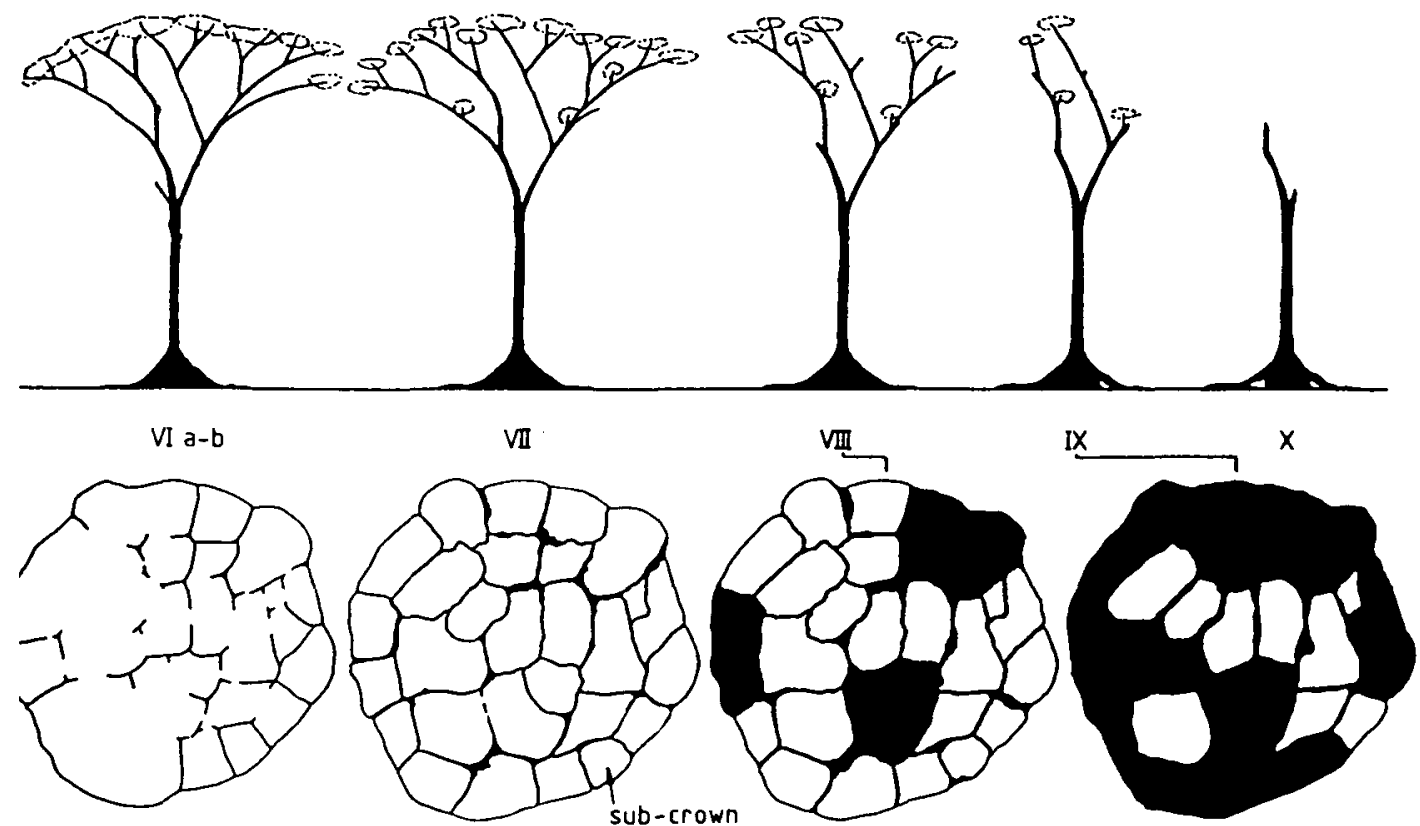

Fig. 1b (bottom). Stages IV-IX. Development of crown shyness in the crown of P.africanum, as observed from aerial photographs.

The space between the sub-crowns and the gaps within the original foliage are indicated in black. 
final stages of the life of $P$. africanum the different sub-crowns are shed and the crown collapses.

By the use of the same morphological crown features, that served for ageing classification in the field, the ageing stages of $P$. africanum could be determined from the aerial photographs. In these photographs the proposed measure for crown shyness could be evaluated unambiguously (Offermans, 1986).

Infrared-sensitive black-and-white film does not provide supplementary information on the senescence of $P$. africanum if infrared reflection is used as a criterion.

Crown shyness. Several authors have described the phenomenon of crown shyness (Jacobs, 1955, Ng, 1977). Jacobs (1955) described crown shyness as the result of the wind induced, abrasive action of crowns brushing against each other. Another codeterminant of crown shyness in $P$. africanum might be the overall growth of the tree. Height growth of the main branches has to be accompanied by an increasing number of sub-crowns or lateral growth of the sub-crowns, to keep the foliar surface of the crown closed. Growth also increases the bending force applied at the junction of branch and trunk, which results in a more obtuse branch angle and a growing distance between the sub-crowns. However, these mechanisms already affect $P$. africanum before crown shyness reveals itself in stage VIb (Fig. 1).

Jacobs (1955) and Zimmermann (1983) stated that the translocation of water and assimilates becomes less efficient with increasing branching order. In the crown-shy stages of $P$. africanum, the foliage is restricted to the zone of highest branching orders. The tree then is incapable to fill up the space between the sub-crowns, which has arisen due to wind and growth. Consequently, crown shyness in $P$. africanum indicates a phase of declining vigour, first expressed in the least competitive parts of the crown. After reiteration capacities of branches of highest order are strongly reduced, decay will affect the sub-crowns, especially at their margin, where the latestformed branches are found (cf. Hallé et al., 1978). The process of crown shyness then accelerates.

\section{References}

Alexandre, D. Y., 1983. Strata in tropical-rain forest at Tai (Ivory Coast), p. 15-24. In: S. L. Sutton, T. C. Whitmore \& A. C. Chadwick (Eds.), Tropical rain forests: ecology and management. Blackwell Scientific Publishers, Oxford.

Anonymus, 1974. Dabema. Bois et Forêts des Tropiques 156: 27-38.

Hallé, F., Oldeman, R. A. A. \& P. B. Tomlinson, 1978. Tropical trees and forests: an architectural analysis. Springer, Heidelberg, $441 \mathrm{pp}$.

Jacobs, M. R., 1955. Growth habits of the Eucalypts. Government printer, Canberra, 262 pp.

Leopold, A. C., 1975. Aging, senescence, and turnover in plants. BioScience 10: 659-662.

$\mathrm{Ng}$, F. S. P., 1977. Shyness in trees. Nature Malaysiana 2: 34-37.

Offermans, D. M. J., 1986. Kroonschuwheid in grootschalige luchtopnamen van Piptadeniastrum africanum (Mimosaceae). [Crown shyness in large-scale aerial photographs of Piptadeniastrum africanum (Mimosaceae).], Dutch, English summary. Landbouwhogeschool, Wageningen, 51 pp.

Offermans, D. M. J., in press. Luftaufnahmen aus geringer Flughöhe: der Einsatz von Ultraleichtflugzeugen in tropischen Regenwäldern. In: Luftaufnahmen aus geringer Flughöhe, Tagung ISPRS (2021 März 1986, Bochum).

Vooren, A. P., in prep. The ecological basis for sustained timber yield management of the West African rain forest. Landbouwhogeschool, Wageningen. 
Vooren, A. P. \& D. M. J. Offermans, 1985. An ultralight aircraft for low-cost, large-scale stereoscopic aerial photographs. Biotropica 17: 84-88.

Zimmermann, M.H., 1983. Xylem structure and the ascent of sap. Springer, Heidelberg, 143 pp.

This synopsis is based on a M. Sc. thesis by Don M. J. Offermans entitled 'Field and aerial observations on Piptadeniastrum africanum (Hook. f.) Brenan, with special reference to ageing', Department of Silviculture, Agricultural University, Wageningen, 1985. $x+83$ pp., 26 figs., 4 tables, 71 refs., 6 appendices.

Available as paper copy (order R058P, $f 20$ including postage) or microfiche (order R058M, f 12.50 including postage) at: NARD, c/o Pudoc, P.O. Box 4, 6700 AA Wageningen, Netherlands (telex 45015 blhwg nl).

\title{
Measured and simulated drought stress effects on daily shoot and root growth rates of soybean*
}

Gerrit Hoogenboom ${ }^{1}$, M. G. Huck ${ }^{2}$ and Curt M. Peterson ${ }^{3}$ ('Department of Agricultural Engineering, University of Florida, Gainesville, FL 32611, USA; ${ }^{2}$ USDAARS, Department of Agronomy, University of Illinois, Urbana, IL 61801, USA; ${ }^{3}$ Department of Botany, Plant Pathology and Microbiology, Alabama Agricultural Experiment Station, Auburn University, Auburn, AL 36849, USA)

Received 29 May 1986; accepted 30 July 1986

\begin{abstract}
The effects of drought stress upon daily shoot and root growth rates of soybean (Glycine max [L.] Merr. 'Braxton') were investigated in experimental studies at the Auburn rhizotron, and in computer simulation studies. Plants were grown in loamy sand and received only rainfall (nonirrigated, NI), or rainfall plus additional irrigation (IR) over the entire growing season. Shoot and root growth followed characteristic exponential growth curves during early vegetative development when no moisture stress was evident. When water stress was imposed during the later stages of vegetative growth or early reproductive development, an increase in root growth rate and a decrease in shoot growth rate was observed in the NI treatment. However, after periods of rainfall, the soil profile was rewet and shoot growth of NI plants was optimal. Thus, long term effects of water stress on final shoot size were not evident. Stimulation of root growth during water stress periods was less pronounced after plants had reached the pod development stage. In ad-
\end{abstract}

\footnotetext{
* Alabama Agricultural Experiment Station Paper 6-861010
} 